\title{
J-DEPACE
}

JOURNAL OF DEDICATION TO PAPUA COMMUNITY

JURNAL PENGABDIAN MASYARAKAT

J-DEPACE, Volume 3, Nomor 2, Desember 2020, Hal 250-255

Tersedia online di :http://jurnal.lpmiunvic.ac.id/index.php/jpkm

\section{UPAYA PENANGGULANGAN PANDEMI COVID-19 DI PANTI ASUHAN KOTA SORONG}

\author{
Natasya Virginia Leuwol.S.SI.,M.Si ${ }^{1}$, Melda A. Manuhutu.S.Kom, M.Cs ${ }^{2}$, \\ Sherly Gaspersz,S.Pd.,M.Pd ${ }^{3}$, Lulu Jola Uktolseja,S.Pd.,M.Pd, \\ Dr.Tagor Manurung,S.E., $\mathrm{MM}^{5}$, Jalmijn Tindage, S.Sos., $\mathrm{MM}^{6}$ \\ Universitas Victory Sorong \\ ${ }^{1}$ natasya.leuwol@gmail.com, ${ }^{2}$ melda.a.manuhutu@gmail.com, \\ ${ }^{3}$ sherlygaspersz91@gmail.com, ${ }^{4}$ lulujola39@gmail.com, ${ }^{5}$ \\ tagormanurung24031963@gmail.com, ${ }^{6}$ jalmijn@unvicsorong.ac.id
}

\begin{abstract}
ABSTRAK
Covid-19 merupakan penyakit menular yang bermula dari Wuhan, China. Sekitar lebih dari 200 negara di dunia terjangkit virus covid-19 dan banyak menimbulkan korbanjiwa dalam waktu yang sangat cepat. Pemerintah melakukan pembatasan kegiatan masyarakat sebagai upaya memutus mata rantai penyebaran virus covid-19. Pencegahan penyebaran penyakit menular tersebut harus segera dilakukan dengan tepat. Terjadinya pandemi global Covid-19 tentu saja berpengaruh besar terhadap aktivitas sehari-hari maupun kegiatan pembelajaran dari anak-anak panti asuhan. Demikian juga dengan pemenuhan kebutuhan pokok mereka. Apalagi masalah utama dari Covid-19 tidak hanya tentang akibat yang ditimbulkan oleh virus terhadap penderita tetapi juga tentang penularannya yang sangat cepat. Oleh karena itu untuk membantu menanggulangi krisis karena Covid- 19 maka beberapa dosen Universitas Victory Sorong dan beberapa orang mahasiswa memberikan bantuan untuk penghuni panti asuhan di Kota Sorong. Harapannya dengan kegiatan ini dapat meringankan beban penghuni panti asuhan yang tentunya ikut merasakan dampak akibat pandemi Covid-19.
\end{abstract}

Kata kunci : Covid-19, panti asuhan, penanggulangan

\section{ABSTRACT}

Covid-19 is a contagious disease, which originated in Wuhan City of China. Nearly 200 countries in the world are infected with the covid-19 virus and claiming thousands of human lives in a short time. The occurrence of the Covid-19 pandemic certainly affected the daily activities and learning activities of the orphanage children. Especially, the fulfillment of their basic needs. Moreover, the main problem of Covid-19 is not only about the effects by the virus on sufferers but also about its rapid transmission. Therefore, to help the crisis due to Covid-19, several lecturers and students from Universitas Victory Sorong for residents of Sorong orphanage. It is hoped that can help the residents of the Sorong orphanage who certainly feel the impact of the Covid-19 pandemic.

Key words : Covid-19, orphanage, handling 


\section{PENDAHULUAN}

Pandemi korona virus 2019 merupakan pandemi penyakit corona virus yang sedang berlangsung 2019 (Covid-19) yang disebabkan oleh sindrom pernafasan akut yang parah yakni coronavirus 2 (SARS-CoV-2). Wabah itu diidentifikasi di Wuhan, Cina, pada Desember 2019, dinyatakan sebagai Darurat Kesehatan Masyarakat dari Kepedulian Internasional pada 30 Januari 2020, dan diakui sebagai pandemi oleh Organisasi Kesehatan Dunia pada 11 Maret 2020. Pada 13 April 2020, lebih dari 1,85 juta kasus Covid-19 telah dilaporkan di 210 negara dan wilayah, mengakibatkan lebih dari 114.000 kematian. Lebih dari 438.000 orang telah pulih, meskipun mungkin ada kemungkinan infeksi ulang. Angka kasus infeksi bervariasi secara signifikan antar negara.

Virus ini terutama menyebar diantara orang-orang selama kontak dekat, sering melalui tetesan kecil yang dihasilkan selama batuk, bersin, atau berbicara. Sementara tetesan ini diproduksi saat bernafas, mereka biasanya jatuh ke tanah atau ke permukaan daripada menular pada jarak yang jauh. Orang juga dapat terinfeksi dengan menyentuh permukaan yang terkontaminasi dan kemudian wajah mereka. Virus ini dapat bertahan di permukaan hingga 72 jam. Penyakit ini paling lama menular selama tiga hari pertama setelah timbulnya gejala, meskipun penyebaran mungkin terjadi sebelum gejala muncul dan pada tahap selanjutnya penyakit.

Masalah utama dari pandemi ini adalah penularan virus yang terjadi sangat cepat. Sehingga setiap orang diharuskan untuk melaksanakan sosial distancing, menjaga kebersihan dan kesehatan diri serta lingkungan. Karena virus ini sudah menyebar di masyarakat di sebagian besar dunia, dengan banyak yang tidak tahu di mana atau bagaimana mereka terinfeksi. Oleh karena itu beberapa orang dosen dari Universitas Victory Sorong, melaksanakan kegiatan pengabdian kepada masyarakat dalam bentuk berbagi, dengan menyerahkan bantuan kepada penghuni panti asuhan yang ada di Kota Sorong.

Saat mewabahnya penularan Covid-19 sekarang ini tentu saja berdampak pada kegiatan belajar maupun pemenuhan kebutuhan pokok sehari-hari oleh penghuni panti asuhan. Ada juga beberapa penghentian bantuan tetap oleh donatur ke panti asuhan. Oleh karena itu dibutuhkan solusi yang konkrit untuk membantu kelancaran kegiatan anak-anak panti asuhan selama masa pandemi. 


\section{MASALAH}

Masalah utama dalam kegiatan kami ini adalah, kondisi pandemi ini, dengan proses penularan virus yang terjadi sangat cepat. Virus ini sudah menyebar di masyarakat di sebagian besar dunia, dengan banyak yang tidak tahu di mana atau bagaimana mereka terinfeksi. Mewabahnya Penularan Covid 19, tentu saja berdapak pada kegiatan belajar maupun pemenuhan kebutuhan pokok sehari hari oleh penghuni panti Asuhan di Kota Sorong.Ada juga beberapa menghentikan bantuan tetap oleh donatur ke panti asuhan.Oleh karena itu, kami tim dosen dan mahasiswa dari Universitas Victory Sorong, memikirkan sebuah solusi yang kongkrit yang dapat membantu panti asuhan yang ada di Kota Sorong, pada masa Pandemi.

\section{METODE PELAKSANAAN}

Kegiatan pengabdian dilaksanakan pada hari Sabtu, tanggal 29 Januari 2021 dengan khalayak sasaran adalah pembina dan pengurus panti asuhan di Kota Sorong dan beberapa anak penghuni panti asuhan. Pelaksanaan kegiatan dilakukan oleh beberapa dosen dan beberapa mahasiswa. Berhubung karena dalam kondisi pandemi Covid-19 maka kegiatan hanya dilakukan di halaman depan panti atau di ruangan sesuai dengan prosedur kesehatan. Kegiatan diawali dengan perkenalan tim pengabdian masyarakat dan pengurus panti asuhan oleh moderator. Tim juga menjelaskan tujuan dari kegiatan ini kepada peserta. Karena kondisi yang tidak memungkinkan untuk berkumpul maka tim pengabdian sudah membawa hand sanitizer, masker dan desinfektan sebelumnya. Acara kemudian dilanjutkan dengan pemberian bantuan berupa Sembako, hand sanitizer, dll. Acara diakhiri dengan doa.

\section{HASIL DAN PEMBAHASAN}

Adapun hasil dan pembahasan dari kegiatan pengabdian kepada masyarakat sebagai bentuk implementasi Tri Dharma Perguruan Tinggi untuk membantu Masyarakat khususnya di Panti Asuhan yang ada di Kota Sorong, adalah sebagai berikut:

Acara dibuka oleh moderator dan diawali dengan perkenalan tim pengabdian kepada beberapa pengurus panti asuhan di Kota Sorong. Tim terdiri dari 6 orang dan 4 orang mahasiswa. Dari dihadiri oleh ketua pembina yayasan dan beberapa anak-anak panti asuhan. Selanjutnya yaitu kata sambutan dari Wakil Rektor I Universitas Victory Sorong. Pada kesempatan ini beliau menyampaikan bahwa Tim dari Universitas Victory Sorong ini memfasilitasi para dosen untuk melaksanakan kegiatan pengabdian yang berhubungan dengan Covid-19. Harapannya kegiatan ini dapat membantu kelancaran kegiatan para penghuni panti asuhan selama pandemi Covid-19. 


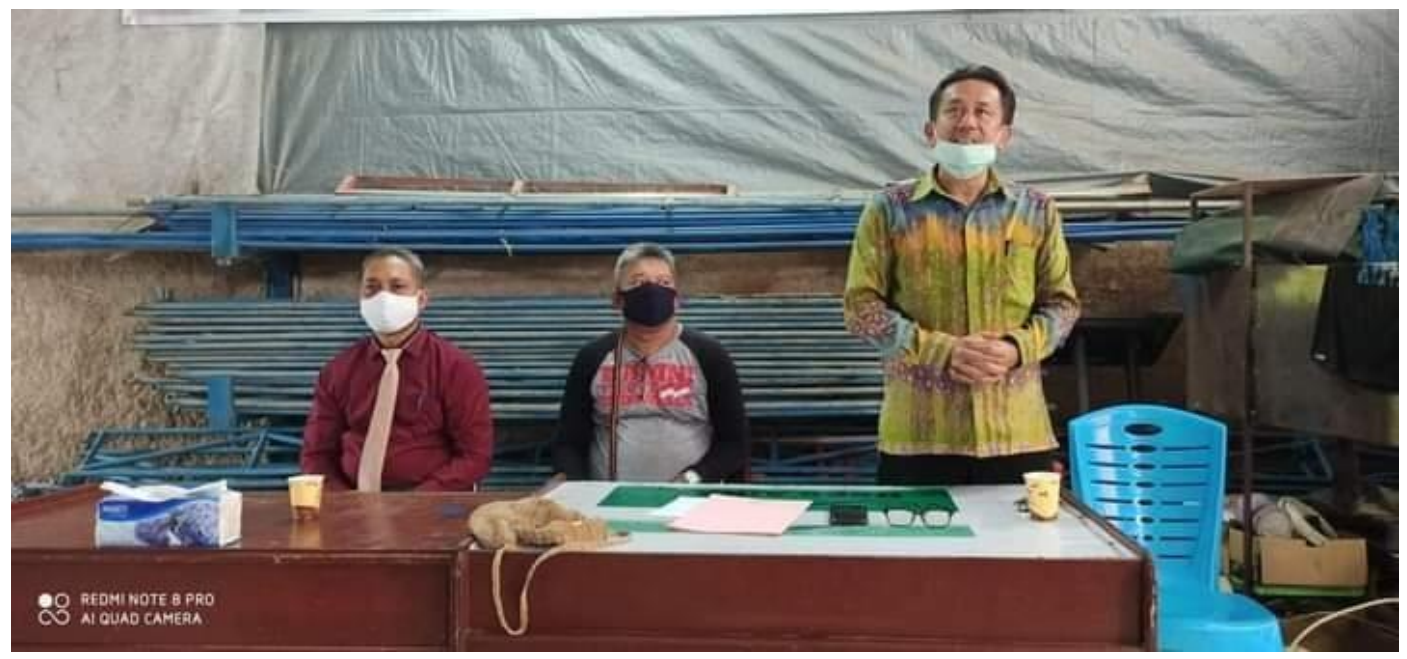

Gambar 1. Kata Sambutan oleh Wakil Rektor I, Universitas Victory Sorong

Pada kesempatan ini pengurus panti asuhan juga menyampaikan bahwa selama pandemi Covid-19 ini anak-anak panti asuhan yang masih memiliki keluarga tapi berasal dari keluarga miskin dikembalikan ke keluarga masing-masing, sedangkan anak-anak yang tidak memiliki keluarga beberapa ada yang masih tinggal di asrama dan beberapa ada yang tinggal bersama pengurus panti asuhan. Mereka sangat antusias menerima bantuan dari tim pengabdian masyarakat yang tentunya sangat berguna untuk membantu pelaksanaan kegiatan selama pandemi dan memenuhi kebutuhan sehari-hari. Apalagi kegiatan usaha yayasan untuk menunjang kebutuhan penghuni panti saat ini tidak berjalan dengan maksimal. Harapannya pandemi ini segera berakhir dan kegiatan di panti asuhan dapat berjalan normal kembali.

Kegiatan kemudian dilanjutkan dengan pemberian bantuan berupa hand sanitizer, desinfektan, masker dan Sembako secara simbolis oleh Tim pengabdian kepada ketua yayasan. Acara kemudian ditutup dengan doa oleh salah satu dosen guru. Semoga kegiatan ini berguna dan diberkati, semua tim pengabdian dan pengurus serta penghuni panti asuhan yang ada di Kota Sorong selalu dalam keadaan sehat dan terhindar dari penularan Covid-19. Harapannya pandemi Covid-19 segera berlalu sehingga segala aktivitas bisa kembali berjalan normal dan lancar. 

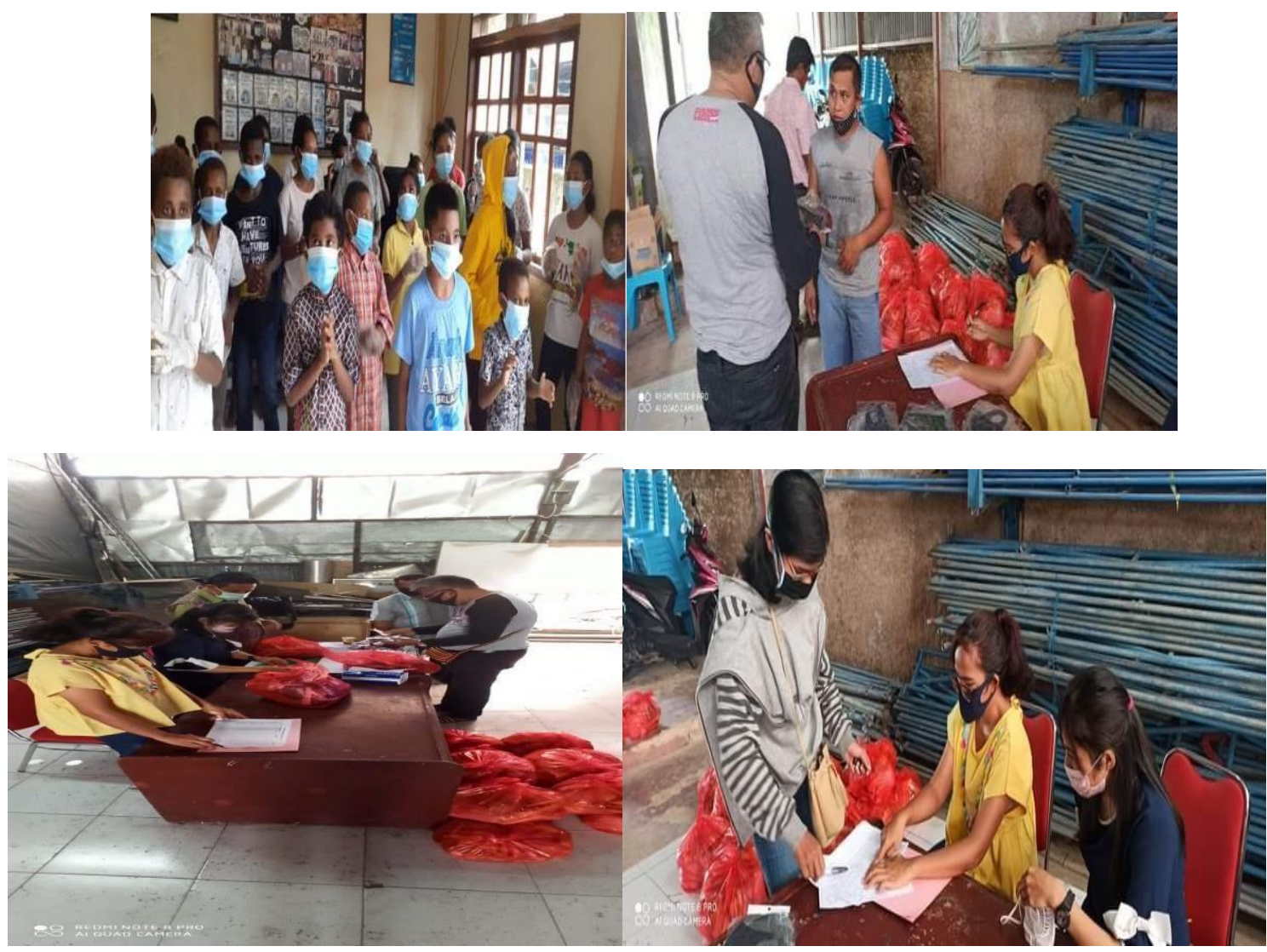

Gambar 2. Pemberian Bingkisan dari Tim Universitas Victory Sorong, kepada Panti Asuhan, di kota Sorong.

\section{KESIMPULAN}

Kegiatan ini bekerja sama dengan Lembaga Penelitian Dan Pengabdian Masyarakat (LPPM) di Perguruan Tinggi Universitas Victory Sorong. Dari kegiatan Pengabdian kepada masyarakat ini, hal yang dapat kami refleksikan menjadi bentuk simpulan kegiatan adalah, Meskipun dalam suasana pandemi Covid-19, acara pengabdian berlangsung dengan lancar dan sesuai dengan rencana. Kegiatan ini mendapat respon yang sangat positif dari pengurus dan anakanak panti asuhan yang ada di Kota Sorong, karena dalam kondisi sekarang tentu saja mereka sangat membutuhkan bantuan terutama secara materil agar kegiatan sehari-hari dan proses belajar mengajar dapat berjalan dengan lancar. Tim Pengabdian dari Universitas Victory Sorong, juga berharap kegiatan ini bisa berlanjut dan berkesinambungan. 


\section{UCAPAN TERIMA KASIH}

Kegiatan pengabdian kepada masyarakat ini terlaksana berkat dukungan Tim Dosen dan beberapa mahasiswa Universitas Victory Sorong, bekerja sama dengan panti asuhan yang ada di kota Sorong.

\section{DAFTAR PUSTAKA}

WHO. “Penyakit Coronavirus 2019”, Organisasi Kesehatan Dunia . Diakses pada 15 Maret 2020 .

WHO.” Pernyataan tentang Pertemuan Kedua dari Komite Kesehatan Internasional (2005) Komite Darurat Mengenai Wabah Virus Coronavirus Baru (2019-CoV)”Organisasi Kesehatan Dunia, 30 Januari 2020. Diarsipkan dari Aslinya Pada 31 Januari 2020. Diakses Pada 30 Januari 2020. 